\title{
Contract (Akad) in Online Banking
}

\author{
Anitha Binti Rosland \\ Department of Syariah \& \\ Economy \\ University of Malaya
}

\author{
Nurhanani Binti Romli \\ Department of Syariah \& \\ Economy \\ University of Malaya
}

\author{
Joni Tamkin Bin Borhan \\ Department of Syariah \& \\ Economy \\ University of Malaya
}

\begin{abstract}
Internet banking is the latest alternative used by the client to deal with the bank. In this way, the customer can surf the bank website without the hassles of queuing and waiting at the counter. This study will discuss about Internet banking services in terms of Islamic transaction. Where, study touches on contract applications found in banking services. The study found that Internet banking services is allowed in Islam and the contract valid even in the early emergence of Islam's Internet technology sophistication yet exists.
\end{abstract}

\section{Keywords}

internet banking, Islamic banking, contract, ijab and qabul

\section{INTRODUCTION}

The existence of the Internet can make a world without boundaries, in other words, the Internet allows us to connect with anyone without having to come face to face and take a long time. Internet use is not only limited to searching for information, education, communication channels, and entertainment, and even the Internet has become a source of income to the community. In Malaysia, the statistics of Internet users in 2011 was a total of $17,723,000$ or $61.7 \%$ of the Malaysian population (Internet Usage Statistics, 2011). These data clearly show the importance of the Internet in everyday life people in Malaysia so the Internet is becoming a necessity among Malaysians.

Internet development has indirectly led to the emergence of on-line banking or also known as Internet banking. Internet banking allows customers to conduct financial transactions on the website of the banks safely. It is also very useful and provide a simple and useful approach to managing one's financial as it is accessible 24 hours a day and seven days a week. There are a variety of banking transactions that can be done which are as checking account balances, pay bills, transfer funds to other accounts and so on. (Nauman Zahid et. al., 2010)

Internet banking is a service provided by the bank to the bank account holders to help customers manage their finances from home or at work or anywhere that has Internet access services. With the rapid use of the Internet, this new way of trading eventually will dominate the modern business and replace the traditional way of business because it offers many advantages, particularly it saves time and energy and convenience for customers.

However, the question that arises is the extent to which Internet-mediated transactions are consistent Islamic principles that have been discussed by members of the jurisprudence since time immemorial. In this research will discuss about the explanation of the questions that exist in the implementation of Internet banking covenants in place, the formation of the contract and the contract defects that occur in Internet banking.

\section{LITERTURE REVIEW}

Nasrul Muhamad Nor Hisham (2008) discussed the application of science and technology used in Islamic transaction in the present and to what extent such applications justifiable in the context of Fiqh Muamalah. The author has briefly describe the applications of science and technology in Islamic transaction. Further discussion focused on the tenets of the contract from the perspective of Islamic contract law and how they are included in transactions in the development of science and technology today.

Azlin Alisa Ahmad et. al. (2008) have argued Internet business from the aspect of maslahah and mafsadah arising therefrom. Results from this study found that the Internet is able to preserve the benefit of business and society as a whole harmony. In addition, the flexible nature of the application maslahah able to bring to the advancement and modernization, and does not prevent the reforms made in accordance with this era of globalization, in particular the Internet transactions that do not exist ruling in al-Quran and al-Sunnah.

Nor Adila Mohd Noor and Noor Mohd Nor Almaz (2008) have discussed the theory of contracts from the perspective of conventional and Islamic transaction. The discussion focused on the concept of contract that practiced in sale and purchase transactions of e-commerce and contracts of sale transactions of Islamic transaction by making a comparative study between the two. Critical evaluation of the entire element in ecommerce contract also done to determine whether or not it coincides with the contract required by law.

Rohaya Shaari et. al. (2005) discuss the outlook for bank officials of Internet banking services. The writer was commenting on the history of Internet banking in Malaysia. In this study the author has distributed questionnaires to the bank manager in northern Malaysia. The study found that although the Internet banking services to customers otherwise increase Internet banking is seen to reduce the human resources and the bank-customer relationship. Therefore, this study suggests the bank manager to continue to offer a personal service to its customers and Internet banking used to complement and enhance banking operations.

Muhammad Rizal Razman (2001) discussed the business transactions that occur in e-commerce from the perspective of Islamic law and its implications for community development. This study also debate about the concept of purchase as well as principles and conditions involved in the selling process. The results showed that trading is done in cyberspace is allowed according to Islamic law. To ensure that the sale is valid, then the transaction must fulfill and perform all of the tenets outlined in Islamic jurisprudence. 


\section{RESEARCH METHODOLOGY}

In achieving the objectives of this study, the authors have identified a number of methods that can be used in collecting and analyzing data. The data were collected and analyzed to produce an authoritative study and achieve the desired objectives of the study.

Generally the research conducted using method of data collection through library research. The data obtained are of materials consisting of books in Arabic, Islamic banking and finance books, journals and other materials in the library or resource center of knowledge.

To analyze the data anyway, the three methods of data analysis have been used namely inductive method, deductive method and the comparative method. Inductive method is a way of analyzing the data to look for evidence than the arguments that are specific to achieve a general proposition. This method is used to create the defining and explaining the functions and development of Internet banking in Malaysia.

When the deductive method is a way of analyzing the data and do the writing on the facts that are common to the facts of a specific nature. This method is used to analyze the deeds and contemporary fatwa relating to transactions in Internet banking.

Comparative method is making a comparison between the data collected to obtain an accurate conclusion with research problems. This method is by making a comparison between the existing provisions in the act with the fatwa or the books of fiqh contemporary.

\section{CONTRACT IN ISLAM}

Akad is a contract built on the requirements of two or more parties will bring something effect of legislation (Zaharuddin Abd. Rahman, 2009). According to al-Jurjani, the contract is the bond act through bargaining process (ijab) and acceptance (qabul). According to the terminology of jurists, sale contract is the contract that refers to the exchange of a property with other property for the purpose of permanent ownership. That is, the contract must be the exchange of property for the purpose of ownership. Sale and purchase must also involve an Islamic judge as property. This type of transaction should also involve the assignment of ownership and possession and can not be fixed for a certain period only (Zulkifli Mohammad AlBakri, 2011).

According to Maliki jurists, defines the transaction from the perspective of Islamic law, which is a contract that contains exchange of goods between the two parties do contract. Hanbali jurists also defines trading as the exchange of goods with other goods in exchange for ownership (Abi Muhammad Abdullah Ibn Ahmad, 1972). Syafie jurists are of the opinion that the sale and purchase agreement in accordance with Islamic term is the exchange of goods with other goods through certain ways. Although the definitions issued by members of the Fiqh is slightly different from one another but all these definitions agree in linking trading as conversion to something.

Wahbah al-Zuhaily (1973) divides contract definition into two categories, general and specific. Generally, the contract is intended by each individual thing to do whether it is the result of a requirement (one side) as endowment, debt recovery, divorce and oaths or it requires two requirements (two parties) to be implemented as a sale and purchase, rental, representation and charges. In particular about it is the bond between the agreement (ijab) and acceptance (qabul) in accordance with Islamic and produce effects in place. It is a common definition adopted by Islamic scholars in defining contract.

Each contract is certainly having its own pillars for this contract exist. These pillars has its own requirements so that it is accepted as legitimate and provide specific implications namely some laws set by Allah SWT. There are three important tenets of the sale contract is a binding contract, contract sighah (ijab and qabul), sales of goods and the prices (Ma'qud alaih).

\section{INTERNET BANKING IN MALAYSIA}

Internet banking application on Islamic banking products is a means to develop more products to the better stage, the customer becomes easier to deal with the bank. It is intended, both sides get their benefits. This effort should be given due attention so that goals can be realized uphold Islamic transactions, and is able to move in tandem with conventional products.

Internet banking means offering banking products and services through the Internet by banking institutions using a variety of facilities including computer access and other advanced equipment. Internet banking can also be defined as a service that does not require in any software or special access to a private network, but it is done through the Internet. Internet banking allows users to manage financial matters in anywhere around the world during or outside banking hours.

The technology is growing rapidly cause banking institutions in Malaysia are also moving forward in providing services in accordance with the latest technology. Thus the existence of alternative channels through bank electronic banking services such as Automatic Teller Machine (ATM), phone banking, PC banking and Internet banking as a facilitator.

The earliest form of electronic channels evident in the Malaysian banking industry was the emergence of ATM in 1981 (Suganthi, R., Balachandher, K.G., dan Balachandran, V., 2001). Another type of electronic channels have been introduced around the 1990's was phone-banking (Guru, B.K., Vaithilingam, S., Norhazlin Ismail dan Prasad. R., 2000). Delivery method is different which customers need to call and break the Automated Voice Response (AVR) for assistance bank services. The third generation of electronic banking revolution also is PC-banking or also known as desktop banking. This method requires a relatively high cost to install intranet facilities and purchase related software. Therefore, it is more popular among corporate customers than individual customers. Then followed by internet banking.

Malaysian Central Bank (Bank Negara Malaysia) has granted permission to local commercial banks to provide Internet banking services on June 1, 2000. Consequently, the Malayan Bank (Maybank) as the largest corporate banking in Malaysia has started Internet banking services to customers at 15 June 2000 by introducing maybank2u.com. However, the success of this new channel for banking products and services depends on the increase in the use of new technology applied by the retail consumer and corporate Malaysia.

Hong Leong Bank also has provided banking services in December 2000. Then Southern Bank has also introduced internet banking. Until the beginning of the 21 st century, the Internet banking has been made available as a basic service that should be provided by the Malaysian corporate banking. Only banking institutions licensed under the Banking and Financial Institutions Act 1989 (BAFIA) and the Islamic Banking Act 1983 (IRA) is allowed to offer Internet banking 
services in Malaysia. Can be said of most banks in Malaysia has offered Internet banking service.

\section{CONTRACT IN INTERNET BANKING}

\subsection{Formation of contract}

In internet banking transactions, the bank is offering the contract which is the subject of the services provided by the virtual bank. The banking service users are at the receiving subject of the contract that the services offered by the bank. Users of this service can open the website of certain banks to see the offer of services provided by the bank.

Formation of contract agreement in Internet banking is a written document through Internet network by using computer equipment. With this basic communication in doing contract through Internet banking is based on writing or document. Doing a virtual contract is based on the concept of contracting parties apart (al-gha'iban) that not together at one time and place. (Mat Noor Mat Zain dan Zamzuri Zakariz, 2001)

Final offer made by the bank directly via active website open to organize specific programs that can be accessed by a specific bank account holders who are interested in doing contract as programmed. The bank should provide detailed information on the services offered to get rid of ambiguity or obscurity to Internet banking service users for services. With the consent can be taken into account and it will remain until the appearing of any party that receives it. Consent, which is directed at the general will not stop and end, otherwise it will continue until the agreement is connected with an acceptance or something happens that invalidates.

Acceptance of the parties wish to enter into contracts also typically occur after completed all the required information and agree with certain ways according to the program set by the bank. Acceptance of the offer by the consumer Internet banking can not happen instantly by looking at the offer of services offered as well as have to fill all the desired information, customers first need to choose the services they wish to use.

Fiqh members have agreed that one of the conditions of consent and acceptance is both must be connected. However, in determining what is meant by adjoining ijab and qabul, Fiqh members have different opinions. In Shafi'i opinion acceptance must be born soon or immediately after the agreement without any break in the slightest that is not related to the contract. To avoid contracting parties regret having to make a decision immediately upon receiving consent, Shafi'i highlights the concept khiyar cermony to give freedom to the contract to make a choice whether to continue the contract or otherwise, as long as they are both still in the contract. (Shams al-Din Muhammad Ibn Muahammad al-Khatib al-Sharbini)

While Hanafi and Hanbali view about communicating is agreement and acceptance continuous in a ceremony. This means that when expressed consent of either the acceptance need not be pronounced immediately or almost immediately. Acceptance even be pronounced then for some time during which the contract is still running and both are still in the contract ceremony.

In internet banking, khiar ceremony did not happen at all. This is because the bank and the customer does not meet or interact directly as written contract with correspondence. In conclusion, the Internet banking application holds the view Hanafi and Hanbali because it gives room to the time the contract either to the bank or the customer to think and to consider whether to continue the contract or otherwise.

\subsection{Contract ceremony}

In the contract ceremony, offer and acceptance may be made in two conditions, i.e. whether the two parties are present at a ceremony or in a ceremony in which the parties do not appear to know the supply is made. There are some situations where one party is not present or in the contract. First, contracts with people who are not in the (invisible). If one party makes an offer to sell or buy while the other party is not in the event, then the offer reaches the last party accepts it. The contract is valid. But if the offer is not agreed to by the contract was void.

Second, the contract occurs with intermediate messenger. One of the two contracting parties have sent a messenger or representative of another person to perform the contract. The contract is valid. People who send seemingly appear in person and revealed last bid received by the purchaser. Therefore, the contract is valid. The third is a contract in writing. One of the contracting parties intend to have written to another party who wants to contract. The author may withdraw the letter of offer with conditions in front of the witness. According to Maliki can not be given the opportunity to withdraw prior to the recipient to make a choice within the period specified by $u r u f$.

Covenants formed in Internet banking transactions are based on writing or digital documents, then it could be considered as a contract made by the parties are far apart just like contracting by mail.

Therefore, the contract for this transaction starts as soon as the document or writing from the bank accepted by the consumer of Internet banking. When the offer in the form of writing received by user, and then the contract builds between the bank and the users of Internet banking. After the ceremony ended any party can't cancel the contract except with the consent of the other party.

\subsection{Defects contract}

Pleasure that occurs in Internet banking similar with pleasure that occur in traditional transaction. Where a contract that can not be included with the things that bring defects that allow the contract to cancel such as uncertainty (gharar). Thus, the two parties to the contract must ensure that defect is not recorded in the transaction to ensure that both parties are satisfied with the transaction.

The concept of gharar or uncertainty can occur in Internet banking but the ratio of the occurrence of this problem is very small as it can be done with specific protocols and systems that cause difficult place a fraud or uncertainty.

Prior to Internet banking users usually do a transaction the user will be advised by the bank to first understand the terms and conditions of service before signing up for Internet banking services. It is intended to identify or disseminate any new information by the bank.

This is because Internet banking services also include information about the responsibilities of institutions and customers. In addition it also includes the parties should be held accountable in case of any false or fraudulent transaction. Information related to how to make a complaint and how complaints are investigated and resolved also provided so that any problems that arise such as fraud and uncertainties that occur in a transaction can be completed by the bank in charge. 


\subsection{Muslim views of internet banking}

According to a fatwa issued by the conference Majma al-Fiqh al-Islami the sixth time in Jeddah on 17-23 Sha'ban $1420 \mathrm{H}$ equivalent to 14 to 20 March $1990 \mathrm{M}$. Among the decisions made at the conference in the event of contract between two people who are not in one place, they do not see and hear each other, they are intermediate between the writings, letters or sent messengers, including telegrams, fax or computer then in this situation the contract made between the two to be perfect when an offer is up to the offeree and he accepted. (Zamzuri Zakaria \& Mat Noor Mat Zain, 2008).

This indicates that the transaction is done by using Internet banking service are allowed based on the contract made between two people who are invisible and their intermediate only by a document found on the website of each bank.

\section{CONCLUSION}

Conclusion can be made on the basis of this discussion is that there are contracts in Internet banking services done in writing through digital written documents provided by the bank with the use of computer equipment. That this contract can be attributed to the formation of contract in writing or al-kitabah allowed to the point of trade and it has also been adopted by Islamic scholars. This virtual contract can also pegged to the contract made by the parties or apart while performing the contract that both parties are not together at one place and time.

Based on Islamic law, internet banking concept is to be in accordance with the Islamic view and this proves that Islam is a complete religion which covers every aspect of human life. Even if the time is always circulating and people are becoming more advanced in terms of their thinking and creativity ultimately to the creation of modern tools that facilitate communication among them. Islam is not an obstacle the development, even encouraged the pursuit of happiness the world together with happiness hereafter. This fact proves elasticity of Islam in celebrate the real atmosphere.

\section{REFERENCES}

[1] Abi Muhammad Abdullah Ibn Ahmad. 1972. AlMughni: Juzuk 4. Beirut Dar al-Kitab al-Arabi

[2] Al-Zuhayli, Wahbah. 1973. al-Fiqh al-Islami Wa Adillatuhu. Beirut Dar al-Fikr

[3] Azlin Alisa Ahmad, Muhd Adib Samsuddin dan Mustafa 'Afifi Ab. Halim. 2008. Perniagaan Internet: Antara Maslahah Dan Mafsadah. Seminar Keusahawanan Islam II Peringkat Kebangsaan
[4] Guru, B.K., Vaithilingam, S., Norhazlin Ismail dan Prasad., R. 2000. "Electronic banking in Malaysia: A note on evolution of services and consumer reaction", Journal of Internet Banking and Commerce, Vol. 5

[5] Mat Noor Mat Zain dan Zamzuri Zakariz. 2001. Pembentukan Akad Dalam E-Dagang, Seminar Kebangsaan Undang-undang Perbandingan. National University of Malaysia

[6] Muhammad Rizal Razman. 2001. Transaksi Jual Beli Melalui Internet Dari Perspektif Islam: Implikasi Terhadap Pendidikan Ummah. Jurnal Pendidikan. Jil. 9, Bil. 4., pp. 41-50

[7] Nasrul Hisyam Nor Muhamad. 2008. "Aplikasi Sains Dan Teknologi Dalam Transaksi Muamalah Islam: Rujukan Kepada Rukun-Rukun Akad Mengikut Perspektif Undang-Undang Kontrak Islam", Jurnal Teknologi, 49(E) Dis. 2008: 81-91

[8] Nauman Zahid et. al. 2010. "Consumer Acceptance of Online Banking", European Journal of Economics, Finance and Administrative Sciences

[9] Nor Adila bt Mohd Noor dan Nor Azlina Mohd Noor. 2008. Kontrak E-Dagang: Perbandingan Aqad (Kontrak) Dalam Muamalah Islam

[10] Rohaya Shaari et. al. 2005. Internet Banking : from The Perspective of Malaysian Bankers. Universiti Utara Malaysia

[11] Shams al-Din Muhammad Ibn Muahammad al-Khatib alSharbini. Mughni al-Mukhtãj. Dar al-Fikr. Jld. 2

[12] Suganthi, R., Balachandher, K.G., dan Balachandran, V. 2001. "Internet banking patronage: An empirical investigation of Malaysia", Journal of Internet Banking and Commerce, Vol. 6

[13] Zaharuddin Abd. Rahman, (2009), Panduan perbankan Islam kontrak dan produk asas. Kuala Lumpur: Telaga Biru

[14] Zamzuri Zakaria \& Mat Noor Mat Zain. 2008. "Jual beli dalam e-dagang menurut perspektif muamalat Islam", Isu Fiqh dan Persoalan Semasa. National University of Malaysia

[15] Zulkifli Mohammad Al-Bakri. 2011. Kewangan Islam dalam Fiqh Syafi'i. Kuala Lumpur IBFIM 